\title{
Medication Error pada Tahapan Prescribing dan Dispensing di Apotek "X" Denpasar Periode Januari-Desember 2019
}

\section{Medication Error in Prescribing and Dispensing at " $X$ " Pharmacy in Denpasar in January-December 2019}

\author{
Fitria Megawati ${ }^{1 \bullet}$, I Putu Tangkas Suwantara ${ }^{1}$, Erna Cahyaningsih ${ }^{1}$ \\ ${ }^{1}$ Program Studi Diploma Tiga Farmasi, Fakultas Farmasi, Universitas Mahasaraswati Denpasar, Bali, Indonesia
}

\begin{abstract}
Abstrak: Medication error menurut National Coordination Council forMedication Error Reporting and Prevention (2017) adalah setiap kejadian yang dapat dihindari yang dapat menyebabkan atau berakibat pada pelayanan obat yang tidak tepat atau membahayakan pasien. Penting sebagai petugas kefarmasian dalam menidentifikasi Medication error yang terjadi terkait kemanan dalam pemberian pelayanan kefarmasian di Apotek " $X$ " Denpasar. Tujuan dari penelitian ini untuk mengetahui medication error yang terjadi pada tahap prescribing dan dispensing Apotek " $\mathrm{X}$ " Denpasar dan Persentase Medication error pada proses pelayanan resep di Apotek " $X$ " Denpasar. Jenis penelitian ini adalah deskriptif kualitatif dengan metode observasi dengan desain retrospektif. Metode sampling yang digunakan yaitu purposive sampling sesuai inklusi dan eksklusi. Instrumen penelitian berupa resep yang diterima oleh Apotek " $X$ " Denpasar dan tabel observasi pada prescribing error dan dispensing error. Resep yang dianalisis sejumlah 910 resep dari tanggal 02 Januari 2019 sampai 31 Desember 2019. Persentase prescribing error yaitu 14,06 \% dan persentase dispensing error dari total 910 resep yaitu 2,41 \%. Dengan rata-rata kategori index medication error NCCMERP adalah kategori B yaitu kesalahan sudah terjadi namun dapat diperbaiki oleh farmasi sebelum obat sampai ke pasien. Dengan Medication error pada fase prescribing error di Apotek " $X$ " Denpasar yang paling banyak yaitu tidak ada umur pasien (39,84\%), tidak ada dosis sediaan (10,16\%), resep tidak lengkap (tidak ada tanggal resep dan nama dokter) (19,53\%). Pada fase dispensing error di Apotek " $X$ " Denpasar yang terjadi yaitu kesalahan etiket/label (18,18\%), kejadian salah peracikan (40,91\%).
\end{abstract}

Kata Kunci: Dispensing Error, Medication Error, Prescribing Error

\begin{abstract}
Medication error according to the National Coordination Council for Medication Error Reporting and Prevention (2017) is any event that can be avoided that can cause or result in inappropriate drug treatment or endanger the patient. It is important as a pharmaceutical officer in identifying Medication errors that occur related to security in providing pharmaceutical services at Denpasar " $X$ " Pharmacy. The purpose of this study was to determine medication errors that occur at the prescribing and dispensing stages of Denpasar " $\mathrm{X}$ " Pharmacy and the percentage of Medication errors in the prescription service process at Denpasar " $X$ " Pharmacy. Type of research is descriptive qualitative with a retrospective design. The sampling method used is purposive sampling according to inclusion and exclusion. Research instruments in the form of prescription received by Denpasar " $X$ " Pharmacy and observation tables on prescribing errors and dispensing errors. 910 prescription analyzed from 02 January 2019 to 31 December 2019. The percentage of prescribing errors is $14.06 \%$ and the percentage of dispensing errors of a total of 910 recipes is $2.41 \%$. With the average NCCMERP index medication error category is category $\mathrm{B}$, that is, an error has occurred but can be corrected by the pharmacy before reaching the patient. With Medication errors in the prescribing error phase at the Denpasar " $X$ " Pharmacy the most is that there is no age of patient (39.84\%), no dosage preparation (10.16\%), prescription is incomplete (no prescription date and doctor's name) (19.53\%). In dispensing error phase in Denpasar " $X$ " Pharmacy, there is a label/label error (18.18\%), compounding error (40.91\%).

Keywords: Dispensing Error, Medication Error, Prescribing Error
\end{abstract}

\section{PENDAHULUAN \\ Medication error menurut National Coordination Council for Medication Error}

Reporting and Prevention (2017) adalah setiap kejadian yang dapat dihindari yang dapat menyebabkan atau berakibat pada pelayanan obat

\footnotetext{
• email korespondensi: fitriamega83@unmas.ac.id
} 
yang tidak tepat atau membahayakan pasien. Medication error sampai saat ini tetap menjadi salah satu permasalahan kesehatan yang banyak menimbulkan berbagai dampak bagi pasien mulai dari resiko ringan bahkan resiko yang paling parah yaitu menyebabkan suatu kematian (Aronson, 2009). Menurut Peraturan Menteri Kesehatan RI (2014), Kesalahan pengobatan dapat terjadi dalam tiap proses pengobatan, baik dalam proses peresepan (prescribing), pembacaan resep (transcribing), penyiapan hingga penyerahan obat (dispensing), maupun dalam proses penggunaan obat (administration).

Penelitian oleh Kung et al. (2013), di Rumah Sakit Universitas Bern, Switzerland melaporkan sebanyak 288 terjadi Medication Error dari total 24.617 pengobatan yang diberikan pada pasien, di mana sebanyak 29\% dari medication error berupa prescribing error, 13\% transcribing error, dan $58 \%$ berupa administration error. Pada penelitian yang dilakukan Maalangen et al. (2019) di Poli Interna di IFRS Bhayangkara Manado diketahui bahwa Medication Error yang terjadi pada fase prescribing yaitu karena tidak ada tanggal lahir (usia) 80,12 \%, tidak ada bentuk sediaan $38,85 \%$, tidak ada konsentrasi/dosis sediaan $27,71 \%$, tidak lengkap penulisan resep obat keras $6,32 \%$, tulisan resep tidak terbaca 3,01 $\%$, salah/tidak jelas nama pasien 1,20 \%, tidak ada jumlah obat $0,30 \%$ dan tidak ada aturan pakai $0,30 \%$. Sedangkan pada fase dispensing yang berpotensi menimbulkan Medication Error yaitu terjadi karena pemberian obat di luar instruksi $8,13 \%$, obat yang diserahkan kurang $1,81 \%$, dan penulisan etiket yang salah atau tidak lengkap 0,30 $\%$.

Sehingga penting sebagai petugas kefarmasian dalam menidentifikasi Medication error yang terjadi terkait keamanan dalam pemberian pelayanan kefarmasian di Apotek " $X$ " Denpasar, dikarenakan belum pernah dilakukannya penelitian terkait Medication error pada apotek, sekaligus penelitian ini dapat digunakan sebagai acuan untuk mengurangi angka kejadian Medication error terkait pelayanan resep di Apotek " $X$ " Denpasar dan dapat mengurangi kesalahan yang terjadi dalam proses pengobatan pasien yang dapat berpotensi merugikan pasien ketika pengobatan berada di bawah pengawasan petugas kesehatan yang sebetulnya dapat dicegah.

\section{METOdE PENELITIAN}

Penelitian ini merupakan jenis penelitian deskriptif observasional dengan desain pengambilan data retrospektif, yaitu resep yang masuk ke Apotek " $X$ " Denpasar pada periode Januari- Desember 2019.

Populasi dari penelitian ini adalah semua pasien yang membawa resep ke apotek " $X$ " Denpasar pada periode Januari-Desember tahun 2019. Sampel yang diambil dari populasi yang memenuhi kriteria penelitian.

1. Kriteria Inklusi:

Pasien dengan membawa resep dari tanggal 02 Januari 2019 sampai 31 Desember 2019.

2. Kriteria eksklusi:

a.Resep yang dibatalkan/tidak diambil oleh pasien.

b.Pasien yang meninggal

Teknik pengambilan sampel dalam penelitian ini menggunakan metode probability sampling dengan teknik random sampling dari populasi 1000 resep. Digunakan rumus slovin menentukan besaran sampel. Hasilnya digunakan 910 sampel resep dari Januari-Desember 2019.

Data yang dicatat adalah keseluruhan informasi yang ada pada resep kemudian dimasukkan ke dalam lembar/tabel observasi untuk dilihat kejadian error sesuai parameter yang diamati. Parameter prescribing error yaitu tulisan resep tidak terbaca, tidak ada nama pasien, tidak ada umur pasien, duplikasi terapi (poli farmasi), tidak ada umur pasien, tidak ada nama obat, tidak ada bentuk sediaan, tidak ada dosis sediaan, tidak ada jumlah obat, tidak ada aturan pakai, kesalahan nama/merk obat, pemilihan obat yang tidak sesuai, kesalahan dosis dan penulisan angka desimal, dosis tidak sesuai dengan kekuatan sediaan, kontraindikasi, resep yang tidak lengkap, dan interaksi obat. Parameter dispensing error yaitu kesalahan penyerahan obat pasien kesalahan penulisan copy resep/salinan resep, kejadian lupa 
memberikan obat pada pasien, tidak ada informasi mengenai obat yang diberikan, pemberian obat kadaluarsa, kesalahan etiket/label, kejadian salah peracikan, kesalahan membaca resep LASA, kesalahan jumlah obat yang diberikan, pemberian dosis yang tidak tepat, dan kesalahan pemberian bentuk sediaan.

Data yang diperoleh selama penelitian terhadap pasien disajikan pada tabel 2 , sehingga didapatkan persentase kejadian medication error pada fase prescribing error dan dispensing error. Selanjutnya ditentukan kategori berdasarkan index NCCMERP untuk melihat kategori error yang terjadi.

\section{HASIL DAN PEMBAHASAN}

Tabel 1. Karakteristik Berdasarkan Jenis Kelamin dan Usia

\begin{tabular}{cccc}
\hline No & Karakteristik & Jumlah & Persentase \\
\hline 1 & Jenis Kelamin & & \\
& Laki-Laki & 525 & $58 \%$ \\
& $\begin{array}{c}\text { Perempuan } \\
2\end{array}$ & 385 & $42 \%$ \\
& Umur & & \\
& $10-24$ tahun & 147 & $16 \%$ \\
& $25-40$ tahun & 245 & $27 \%$ \\
& $41-65$ tahun & 295 & $32 \%$ \\
& $>65$ tahun & 223 & $25 \%$ \\
\hline
\end{tabular}

Pada Tabel 1 menunjukkan pasien berjenis kelamin laki-laki menjadi subjek terbanyak dengan jumlah 525 pasien dengan persentase 58\%. Selanjutnya pasien berjenis kelamin perempuan sebanyak 385 pasien dengan persentase $42 \%$. Untuk kategori usia paling banyak yaitu usia 41-65 tahun sebanyak 295 pasien dengan persentase $32 \%$. Berdasarkan hasil penelitian yang dilakukan oleh Sari, dkk (2018), menyatakan bahwa perbedaan pola perilaku sakit juga dipengaruhi oleh jenis kelamin dimana perempuan lebih sering pergi berobat dibandingkan laki-laki.

Penelitian Patel et al. (2018) ini menunjukkan bahwa usia 41-60 tahun kelompok lebih terpengaruh pada medication error, sedangkan berbagai penelitian dilakukan di rumah sakit yang berbeda melaporkan pasien kelompok usia yang sama yang terlibat dalam medication error.

Tabel 2. Jumlah Resep yang Diamati pada periode satu tahun (Januari-Desember 2019)

\begin{tabular}{ccc}
\hline Resep & Jumlah (1 tahun) & Persentase \\
\hline R/ Sp.PD & 279 & $30.65 \%$ \\
R/ Sp.OG & 31 & $3.41 \%$ \\
R/ Sp.JP & 47 & $5.16 \%$ \\
R/ Sp.THT & 168 & $18.46 \%$ \\
R/ Sp.KK & 89 & $9.78 \%$ \\
R/ Sp.S & 20 & $2.20 \%$ \\
R/ Gigi & 18 & $1.98 \%$ \\
R/ Poliklinik & 258 & $28.35 \%$ \\
Jumlah & 910 & $100 \%$ \\
\hline
\end{tabular}

Küng et al. (2013) menyebutkan bahwa salah satunya obat kardiovaskular adalah kelas obat yang paling umum yang terkait dengan medication error. Bahwa kesalahan pengobatan tingkat prevalensi $32 \%$ pada pasien kardiovaskular. Oleh karena itu, medication error dalam pemberian obat-obatan kardiovaskular perlu perhatian khusus, dan dapat diasumsikan bahwa pasien kardiovaskular berada pada risiko yang meningkat untuk terjadinya error. setiap poli pemeriksaan memiliki pola kesalahan dan risiko error yang berbeda. Hal tersebut perlu dipahami tentunya sebagai antisipasi dalam meminimalisir angka kejadian error pada fase prescribing ataupun dispensing. Berikut persentase kesalahan dari resep masing-masing poli pemeriksaan. Dari tabel dibawah ini 910 resep yang terjadi kesalahan prescribing 128 resep dan yang terjadi kesalahan dispensing sebanyak 22 resep.

Tabel 3. Tabel Kesalahan Resep

\begin{tabular}{ccc}
\hline $\begin{array}{c}\text { Kesalahan } \\
\text { Peresepan }\end{array}$ & $\begin{array}{c}\text { Jumlah (dari } \\
\text { total } \mathbf{n : ~ 9 1 0 )}\end{array}$ & Persentase \\
\hline Prescribing & 128 & $14,06 \%$ \\
$\begin{array}{c}\text { Dispensing } \\
\text { Tidak ada }\end{array}$ & 22 & $2,42 \%$ \\
kesalahan & 760 & $83,52 \%$ \\
Jumlah & $\mathbf{9 1 0}$ & $\mathbf{1 0 0 \%}$ \\
\hline
\end{tabular}


Tabel 4 Jumlah Prescribing Error Berdasarkan Asal Resep

\begin{tabular}{|c|c|c|c|c|c|c|c|c|c|c|}
\hline No. & Parameter yang diamati & $\begin{array}{c}\text { R/ } \\
\text { Sp.PD }\end{array}$ & $\begin{array}{c}\mathrm{R} / \\
\mathrm{Sp} . \mathrm{OG}\end{array}$ & $\begin{array}{l}\mathrm{R} / \\
\text { Sp.JP }\end{array}$ & $\begin{array}{c}\text { R/ } \\
\text { Sp.THT }\end{array}$ & $\begin{array}{c}\text { R/ } \\
\text { Sp.KK }\end{array}$ & $\begin{array}{c}\mathrm{R} / \\
\mathrm{Sp} . \mathrm{S}\end{array}$ & $\begin{array}{l}\text { R/ } \\
\text { Gigi }\end{array}$ & $\begin{array}{c}\mathrm{R} / \\
\text { Poliklinik }\end{array}$ & $\mathrm{Jml}$ \\
\hline 1. & Tulisan resep tidak terbaca & 0 & 0 & 0 & 0 & 0 & 0 & 0 & 3 & 3 \\
\hline 2. & Tidak ada nama pasien & 0 & 0 & 0 & 0 & 0 & 0 & 0 & 0 & 0 \\
\hline 3. & Tidak ada umur pasien & 0 & 26 & 0 & 0 & 0 & 0 & 0 & 25 & 51 \\
\hline 4. & Tidak ada nama obat & 0 & 0 & 0 & 0 & 0 & 0 & 0 & 0 & 0 \\
\hline 5. & Tidak ada bentuk sediaan & 0 & 0 & 0 & 0 & 0 & 0 & 0 & 5 & 5 \\
\hline 6. & $\begin{array}{l}\text { Tidak ada dosis (kekuatan) } \\
\text { sediaan }\end{array}$ & 0 & 0 & 0 & 0 & 0 & 0 & 0 & 13 & 13 \\
\hline 7. & Tidak ada jumlah obat & 0 & 0 & 0 & 0 & 0 & 0 & 0 & 1 & 1 \\
\hline 8. & Tidak ada aturan pakai obat & 0 & 0 & 0 & 0 & 0 & 0 & 0 & 1 & 1 \\
\hline 9. & Duplikasi terapi & 0 & 1 & 0 & 0 & 0 & 0 & 0 & 1 & 2 \\
\hline 10. & Kesalahan nama/Merk obat & 0 & 0 & 0 & 0 & 0 & 0 & 0 & 8 & 8 \\
\hline 11. & Kontraindikasi & 0 & 0 & 0 & 0 & 0 & 0 & 0 & 0 & 0 \\
\hline 12. & Interaksi obat & 11 & 0 & 0 & 0 & 0 & 0 & 0 & 0 & 11 \\
\hline 13. & $\begin{array}{ll}\text { Kesalahan } & \text { penulisan } \\
\text { angka/decimal } & \text { kekuatan } \\
\text { sediaan } & \end{array}$ & 0 & 0 & 0 & 0 & 0 & 3 & 0 & 0 & 3 \\
\hline $\begin{array}{l}14 . \\
15 .\end{array}$ & $\begin{array}{l}\text { Kesalahan dosis } \\
\text { Resep tidak lengkap (tidak }\end{array}$ & 0 & 0 & 0 & 0 & 0 & 0 & 0 & 5 & 5 \\
\hline & $\begin{array}{l}\text { ada tanggal resep dan nama } \\
\text { dokter) }\end{array}$ & 0 & 25 & 0 & 0 & 0 & 0 & 0 & 0 & 25 \\
\hline
\end{tabular}

Tabel 5 Jumlah Dispensing Error berdasarkan Asal Resep

\begin{tabular}{|c|c|c|c|c|c|c|c|c|c|c|}
\hline No. & Parameter yang diamati & $\begin{array}{l}\text { R/ } \\
\text { Sp.PD }\end{array}$ & $\begin{array}{c}\mathrm{R} / \\
\mathrm{Sp} . \mathrm{OG}\end{array}$ & $\begin{array}{l}\mathrm{R} / \\
\text { Sp.JP }\end{array}$ & $\begin{array}{c}\text { R/ } \\
\text { Sp.THT }\end{array}$ & $\begin{array}{c}\text { R/ } \\
\text { Sp.KK }\end{array}$ & $\begin{array}{l}\mathrm{R} / \\
\mathrm{Sp} . \mathrm{S}\end{array}$ & $\begin{array}{l}\mathrm{R} / \\
\text { Gigi }\end{array}$ & $\begin{array}{c}\mathrm{R} / \\
\text { Poliklinik }\end{array}$ & $\mathrm{Jml}$ \\
\hline 1. & $\begin{array}{l}\text { Kesalahan penyerahan obat } \\
\text { pasien }\end{array}$ & 0 & 0 & 0 & 0 & 0 & 0 & 0 & 0 & 0 \\
\hline 2. & $\begin{array}{l}\text { Kesalahan penulisan copy } \\
\text { resep }\end{array}$ & 0 & 0 & 0 & 2 & 0 & 0 & 0 & 0 & 2 \\
\hline 3. & $\begin{array}{l}\text { Kejadian lupa memberikan } \\
\text { obat kepada pasien }\end{array}$ & 1 & 0 & 0 & 0 & 0 & 0 & 0 & 0 & 1 \\
\hline 4. & $\begin{array}{l}\text { Tidak ada informasi } \\
\text { mengenai obat yang } \\
\text { diberikan }\end{array}$ & 0 & 0 & 0 & 0 & 0 & 0 & 0 & 0 & 0 \\
\hline 5. & $\begin{array}{l}\text { Pemberian } \\
\text { kedaluwarsa }\end{array}$ & 0 & 0 & 0 & 0 & 0 & 0 & 0 & 0 & 0 \\
\hline 6. & Kesalahan etiket/label & 4 & 0 & 0 & 0 & 0 & 0 & 0 & 0 & 4 \\
\hline 7. & Kejadian salah peracikan & 5 & 0 & 0 & 0 & 4 & 0 & 0 & 0 & 9 \\
\hline 8. & $\begin{array}{l}\text { Kesalahan membaca resep } \\
\text { LASA }\end{array}$ & 0 & 0 & 0 & 0 & 0 & 0 & 0 & 2 & 2 \\
\hline 9. & $\begin{array}{l}\text { Kesalahan jumlah obat yang } \\
\text { diberikan }\end{array}$ & 0 & 0 & 0 & 0 & 0 & 0 & 0 & 2 & 2 \\
\hline 10. & $\begin{array}{l}\text { Pemberian dosis yang tidak } \\
\text { tepat }\end{array}$ & 0 & 0 & 0 & 0 & 0 & 0 & 0 & 0 & 0 \\
\hline 11. & $\begin{array}{l}\text { Kesalahan pemberian } \\
\text { bentuk sediaan }\end{array}$ & 0 & 0 & 0 & 0 & 1 & 0 & 0 & 1 & 2 \\
\hline
\end{tabular}


Pada tabel 4. parameter yang paling banyak menunjukkan ketidaksesuaian dari resep ke-delapan poli pemeriksaan adalah "tidak ada umur pasien" sebanyak 51 resep. Diperoleh dari resep poliklinik dan resep spesialis kandungan. Kelengkapan resep seperti tanggal resep dan nama dokter pemeriksa sebanyak 25 resep dari poli spesialis kandungan. Total kejadian prescribing error periode Januari - Desember 2019 adalah 128 Resep. Pada Tabel 5. dijelaskan bahwa kejadian dispensing error yang paling banyak terjadi adalah kejadian salah peracikan obat sebanyak 9 resep. Resep tersebut dari poli spesialis penyakit dalam sejumlah 4 resep. Total kejadian dispensing error yang terjadi pada periode Januari-Desemeber 2019 di Apotek "X" Denpasar yaitu 22 kejadian.

Tabel 6 Persentase Prescribing Error dan Indeks NCCMERP

\begin{tabular}{|c|c|c|c|c|c|}
\hline No. & Parameter yang diamati & Frekuensi & Persentase & Kategori & Keterangan \\
\hline 1. & $\begin{array}{ll}\text { Tulisan resep tidak } \\
\text { terbaca }\end{array}$ & 3 & $2,34 \%$ & B & Dilakukan konfirmasi ke dokter \\
\hline 2. & Tidak ada nama pasien & 0 & 0 & 0 & - \\
\hline 3. & Tidak ada umur pasien & 51 & $39,84 \%$ & B & $\begin{array}{l}\text { Telusur melalui No.RM/dilakukan konfirmasi } \\
\text { ke pasien/dokter }\end{array}$ \\
\hline 4. & Tidak ada nama obat & 0 & 0 & 0 & - \\
\hline 5. & $\begin{array}{l}\text { Tidak ada bentuk } \\
\text { sediaan }\end{array}$ & 5 & $3,91 \%$ & B & Dilakukan konfirmasi ke dokter \\
\hline 6. & $\begin{array}{l}\text { Tidak ada dosis } \\
\text { (kekuatan) sediaan }\end{array}$ & 13 & $10,16 \%$ & B & Dilakukan konfirmasi ke dokter \\
\hline 7. & Tidak ada jumlah obat & 1 & $0,78 \%$ & B & Dilakukan konfirmasi ke dokter \\
\hline 8. & $\begin{array}{l}\text { Tidak ada aturan pakai } \\
\text { obat }\end{array}$ & 1 & $0,78 \%$ & B & Dilakukan konfirmasi ke dokter \\
\hline 9. & Duplikasi terapi & 2 & $1,56 \%$ & B & $\begin{array}{l}\text { Dilakukan konfirmasi ke dokter, digunakan } \\
\text { untuk target terapi berbeda }\end{array}$ \\
\hline 10. & $\begin{array}{l}\text { Kesalahan nama/Merk } \\
\text { obat }\end{array}$ & 8 & $6,25 \%$ & B & Dilakukan konfirmasi ke dokter \\
\hline 11. & Kontraindikasi & 0 & 0 & 0 & - \\
\hline 12. & Interaksi obat & 11 & $8,59 \%$ & B & $\begin{array}{c}\text { Dilakukan konfirmasi ke dokter, pengaturan } \\
\text { jadwal penggunaan obat }\end{array}$ \\
\hline 13. & $\begin{array}{l}\text { Kesalahan penulisan } \\
\text { angka/decimal kekuatan } \\
\text { sediaan }\end{array}$ & 3 & $2,34 \%$ & B & Dilakukan konfirmasi ke dokter \\
\hline 14. & Kesalahan dosis & 5 & $3,91 \%$ & B & Dilakukan konfirmasi ke dokter \\
\hline 15. & $\begin{array}{l}\text { Resep tidak lengkap } \\
\text { (tidak ada tanggal resep } \\
\text { dan nama dokter) }\end{array}$ & 25 & $19,53 \%$ & B & Dilakukan konfirmasi ke dokter \\
\hline
\end{tabular}

Pada tabel 6. dijelaskan bahwa persentase kejadian error tertinggi pada ketidaksesuaian resep "tidak terdapat umur pasien" dengan persentase kejadian 39,84\%. Tertinggi kedua yaitu resep tidak lengkap (tidak ada tanggal resep dan nama dokter) yaitu $19,53 \%$. Umur pasien merupakan komponen penting dalam administrasi resep. Keamanan dan efikasi suatu terapi dapat dilihat dari umur pasien. Dosis suatu obat ditentukan dari umur pasien selain melalui luas permukaan tubuh misalnya.
Sehingga informasi umur dalam resep menjadi sangat penting terutama dalam menjamin keamanan dan efikasi suatu terapi, terkait dengan dosis dan bentuk sediaan yang diberikan apakah sesuai dengan usia pasien (World Health Organization, 2016). Menurut peraturan perundang-undangan yang berlaku, yang berhak menulis resep adalah dokter, dokter gigi, dokter hewan kepada apoteker untuk menyediakan dan menyerahkan obat bagi pasien (Menkes, 2004). 
Sehingga nama dokter penulis resep wajib untuk ditulis. Selain itu identitas dokter memudahkan petugas farmasi untuk melakukan kordinasi terkait pemberian terapi yang diresepkan oleh dokter tersebut. Tanggal pemberian pada resep sangat penting untuk mengetahui kapan resep tersebut ditulis dan untuk menyiapkan obat yang diminta. Medication error index pada keseluruhan prescribing error termasuk kategori B yaitu error terjadi sebelum mencapai pasien. Kategori ini termasuk error yang tidak membahayakan. Kejadian error tersebut di atas telah dilakukan tindak lanjut antisipasi dengan melakukan telusur melalui Nomor RM/dilakukan konfirmasi kepada pasien atau dikordinasikan ke dokter penulis resep.

Tabel 7 Persentase Dispensing Error dan Indeks NCCMERP

\begin{tabular}{|c|c|c|c|c|c|}
\hline No. & Parameter yang diamati & Frekuensi & Persentase & Kategori & Keterangan \\
\hline 1. & Kesalahan penyerahan obat pasien & 0 & 0 & - & - \\
\hline 2. & Kesalahan penulisan copy resep & 2 & $9,09 \%$ & B & $\begin{array}{l}\text { Terdeteksi saat KIE, dapat } \\
\text { diperbaiki }\end{array}$ \\
\hline 3. & $\begin{array}{l}\text { Kejadian lupa memberikan obat } \\
\text { kepada pasien }\end{array}$ & 1 & $4,54 \%$ & B & $\begin{array}{l}\text { Terdeteksi saat KIE, dapat } \\
\text { diperbaiki }\end{array}$ \\
\hline 4. & $\begin{array}{l}\text { Tidak ada informasi mengenai obat } \\
\text { yang diberikan }\end{array}$ & 0 & 0 & - & - \\
\hline 5. & Pemberian obat kedaluwarsa & 0 & 0 & - & - \\
\hline 6. & Kesalahan etiket/label & 4 & $18,18 \%$ & B & $\begin{array}{l}\text { Terdeteksi saat kaji ulang } \\
\text { kesesuaian obat dengan resep. } \\
\text { Cetak ulang label }\end{array}$ \\
\hline 7. & Kejadian salah peracikan & 9 & $40,91 \%$ & B & $\begin{array}{l}\text { Terdeteksi saat kaji ulang } \\
\text { kesesuaian obat dengan resep. } \\
\text { Dilakukan pengulangan }\end{array}$ \\
\hline 8. & Kesalahan membaca resep LASA & 2 & $9,09 \%$ & B & $\begin{array}{l}\text { Terdeteksi saat kaji ulang } \\
\text { kesesuaian obat dengan resep. } \\
\text { Dilakukan pengulangan }\end{array}$ \\
\hline 9. & $\begin{array}{l}\text { Kesalahan jumlah obat yang } \\
\text { diberikan }\end{array}$ & 2 & $9,09 \%$ & B & $\begin{array}{l}\text { Terdeteksi saat KIE, dapat } \\
\text { diperbaiki }\end{array}$ \\
\hline 10. & Pemberian dosis yang tidak tepat & 0 & 0 & - & - \\
\hline 11. & $\begin{array}{l}\text { Kesalahan pemberian bentuk } \\
\text { sediaan }\end{array}$ & 2 & $9,09 \%$ & B & $\begin{array}{l}\text { Terdeteksi saat kaji ulang } \\
\text { kesesuaian obat dengan resep. } \\
\text { Dilakukan pengulangan }\end{array}$ \\
\hline
\end{tabular}

Pada Tabel 7. dijelaskan bahwa persentase kesalahan tertinggi terjadi pada kejadian salah peracikan sejumlah 9 error dengan persentase $40,91 \%$. Kesalahan pada etiket/label dengan persentase kejadian 18,18\%. Keseluruhan kejadian error yang terjadi termasuk kategori B. Kategori B yaitu error terjadi sebelum mencapai pasien. Kategori ini termasuk error yang tidak membahayakan. Kejadian error tersebut di atas telah dilakukan antisipasi dengan kaji ulang atau pengecekan berulang pada setiap tahapan pekerjaan. Kesalahan pada parameter ini sangat fatal apabila sampai terjadi dikarenakan obat yang sudah diracik tidak bisa diketahui kesalahannya karena sudah tercampur, sehingga perlu ketelitian dan kehati-hatian. Terutama dalam perhitungan bahan, jumlah bahan obat yang diracik dan nama bahan obat harus tepat. Kesalahan pada obat yang diracik menimbulkan resiko tidak tercapainya target terapi. Kesalahan jumlah bahan obat yang dicampur menyebabkan tidak masuk dalam rentang terapi atau masuk pada rentang toksik (Nuryati, 2017). Informasi tentang suatu obat, dapat diperoleh dari etiket atau label yang menyertai obat tersebut. Tujuan pemasangan etiket/label untuk pasien memahami tujuan pengobatan dan mematuhi intruksi pengobatan. Penulisan etiket dan label sebaiknya dikerjakan 
pada saat selesai menyiapkan obat-obatan untuk diserahkan ke pasien. Keseluruhan kejadian dispensing error berdasarkan NCCMERP termasuk kategori B yaitu yaitu kesalahan sudah terjadi namun dapat diperbaiki oleh farmasi sebelum obat sampai ke pasien. Ketidaksesuaian telah terdeteksi saat kaji ulang kesesuaian obat dengan resep.

Dari uraian di atas menunjukkan bahwa persentase terjadinya prescribing error di Apotek "X" Denpasar yaitu $14,06 \%$ dari total 910 resep dan persentase terjadinya dispensing error di Apotek "X" Denpasar adalah 2,41\% dari 910 resep yang diamati. Termasuk dalam rata-rata kategori $\mathbf{B}$ yaitu kesalahan sudah terjadi, namun dapat diperbaiki oleh farmasi sebelum obat diserahkan ke pasien berdasarkan tabel kategori indeks medication error NCCMERP. Pada prescribing error dan dispensing error di Apotek " $X$ " Denpasar menunjukkan indeks medication error NCCMERP adalah kategori B. Hal tersebut dikarenakan di Apotek " $X$ " menerapkan sistem pengkajian ulang pada setiap prosesnya mulai dari fase prescribing hingga dispensing. Sistem Double Check yang dilakukan secara konsisten sehingga farmasi dapat melakukan evaluasi untuk mencegah terjadinya error pada fase menerima resep dari pasien, proses menyiapkan obat hingga menyerahkan obat. Pada saat menerima resep dari pasien, petugas farmasi wajib melakukan skrining resep selanjutnya pada proses menyiapkan obat sesuai resep dilakukan kaji ulang atau pemeriksaan kembali (double check) terhadap kesesuaian antara resep dengan identitas pasien, bentuk dan kekuatan sediaan, jumlah obat, serta aturan pakai obat untuk mencegah terjadinya kesalahan. Begitu pula petugas farmasi yang bertugas menyerahkan obat kembali melakukan pengecekan sebelum obat diserahkan ke pasien. Sehingga tidak ada medication error yang terjadi hingga ke pasien.

Menurut penelitian Razmi, 2017 terdapat beberapa faktor yang dapat mengakibatkan terjadinya medicationerror pada fase prescribing seperti jumlah dokter yang berjaga, jumlah pasien setiap harinya, ketidaktahuan dokter terhadap penulisan resep yang sesuai dengan Peraturan Menteri Kesehatan tahun 2014, ataupun faktor internal yang dialami dokter. Penyebab terjadinya kesalahan dalam penulisan resep adalah faktor lingkungan kerja yaitu gangguan dan interupsi keluarga pasien; faktor pasien yaitu pasien yang tidak kooperatif terhadap kondisinya; faktor petugas kesehatan yaitu tulisan dokter yang buruk, pengetahuan,dan beban kerja yang berlebihan. Pernyataan yang sama yang mendukung faktor penyebab prescribing error menurut Tien W, 2018 dimana kurangnya pengetahuan dan informasi mengenai obat dan pasiennya, kesalahan mental dan fisik penulis resep, beban kerja tinggi, komunikasi tidak berjalan baik, pengawasan terhadap jalannya pengobatan yang kurang, sistem kerja dan sarana yang tidak mendukung, dan kurangnya pelatihan; Faktor penyebabnya dispensing error terjadi akibat kemiripan nama obat (look alike and sound alike), petugas yang kurang berpengalaman, jumlah petugas yang kurang memadai, kesalahan pembacaan dan beban kerja yang tinggi; Faktor penyebabnya administration error kurangnya pengetahuan dalam menggunakan teknologi untuk penyiapan dan pemberian obat, kelelahan dan tidak adanya dukungan.Tentunya sistem ini dilakukan untuk meningkatkan patient safety di Apotek " $X$ " Denpasar.

\section{SIMPULAN}

Berdasarkan hasil penelitian yang telah dilakukan dapat ditarik kesimpulan bahwa Medication error yang terjadi pada fase prescribing error di Apotek " $X$ " Denpasar yaitu tulisan resep tidak terbaca, tidak ada umur pasien, tidak ada bentuk sediaan, tidak ada dosis sediaan, tidak ada jumlah obat, tidak ada aturan pakai obat, duplikasi terapi, kesalahan nama/merk obat, interaksi obat, kesalahan penulisan angka/desimal, kesalahan dosis, resep tidak lengkap (tidak ada tanggal resep dan nama dokter). Pada fase dispensing error di Apotek " $X$ " Denpasar yang terjadi yaitu kesalahan penulisan copy resep, kejadian lupa memberikan obat kepada pasien, kesalahan etiket/label, kejadian salah peracikan, kesalahan membaca resep LASA, kesalahan jumlah obat yang diberikan, kesalahan pemberian bentuk sediaan. Persentase 
medication error dari total 910 resep di Apotek " $X$ " Denpasar adalah $16,47 \%$ yang terdiri dari persentase prescribing error $14,06 \%$ dan persentase dispensing error $2,41 \%$. Dengan ratarata kategori index medication error NCCMERP adalah kategori B yaitu kesalahan sudah terjadi namun dapat diperbaiki oleh farmasi sebelum obat sampai ke pasien.

\section{UCAPAN TERIMA KASIH}

Diucapkan terima kasih yang sebesar-besarnya kepada Pengelola dan Staf Apotek " $X$ " di Denpasar yang telah memberikan ijin pengambilan data dalam penelitian ini, dan kepada semua pihak yang telah membantu proses penelitian ini.

\section{DAFTAR PUSTAKA}

Aronson JK. (2009). Medication errors: Definitions and classification. British Journal of Clinical Pharmacology 67 (6): $599-604$.

Direktorat Jendral Pelayanan Farmasi dan Alat Kesehatan. 2004. Keputusan Mentri Kesehatan Republic Indonesia Tentang Standard Pelayanan Kefarmasian Di Apotek Nomor 1027/MENKES/ SK/IX/2004. Jakarta: Menteri Kesehatan Republik Indonesia

Kung, K., Carrel, T., Wittwer, B., Engberg, S.,Zimmermann, N., \& Schwendimann, R. 2013. Medication Errors in A SwissCardiovascular Surgery Department: ACross-Sectional Study Based on A NovelMedication Error Report Method. Nursing Research and Practice: 4. 1-5.

Maalangen T.V., Gayatri C., Weny I. W. 2018. Identifikasi Medication Error Pada Resep Pasien Poli Interna Di Instalasi Farmasi Rumah Sakit Bhayangkara Tk. III Manado. Pharmacon Jurnal Ilmiah Farmasi. 8(3): 2027.
Menkes RI. 2016. Peraturan Meteri Kesehatan Republik Indonesia Nomor 72 Tahun 2016 tentang Standar Pelayanan Kefarmasian di Rumah Sakit. Jakarta.

National Coordination Council forMedication Error Reporting and Prevention (NCCMERP). 2017.

http://www.nccmerp.org/aboutmedicatio n-errors

Nuryati, 2017. Farmakologi. PPSDM Kementerian Kesehatan Republik Indonesia, Jakarta.

Patel, S., Ashita P., Varsha P., Nilay S. 2018. I Study of Medication Error in Hospitalised Patients in Tertiary Care Hospital. Indian Journal of Pharmacy Practice. 11 (1): 32-36

Razmi, Z., Zahra W., 2017. Kejadian Medication Error Pada Fase Prescibing di Poliklinik Pasien Rawat Jlaan RSD Mayjend HM Ryacudu Kotabumi, Jurnal Kedokteran Unila, Vol.1 Nomer 3: 540-545

Sari, R. P., A. M. P. Putra, dan U. Masran, 2018, Hubungan Pengetahuan Dan Kebutuhan Pasien Terhadap Informasi Obat di Apotek Amandit Farma Banjarmasin, Jurnal Ilmiah Manuntung, 4(2):98-105.

Tien, W. P. 2018, Faktor Penyebab Medication Error Di Rsu Anutapura Kota Palu, Jurnal Pengembangan Sumber Daya Insani, 2(2):224-229

World Health Organization, 2016. Medication Errors: Technical Series on Safer Primary Care. 